\title{
From SARS and MERS to COVID-19: a brief summary and comparison of severe acute respiratory infections caused by three highly pathogenic human coronaviruses
}

\author{
Zhixing Zhu ${ }^{1 \dagger}$, Xihua Lian ${ }^{2 \dagger}$, Xiaoshan Su', Weijing Wu ${ }^{1}$, Giuseppe A. Marraro ${ }^{1,3^{*}}$ and Yiming Zeng ${ }^{1 *}$
}

\begin{abstract}
Within two decades, there have emerged three highly pathogenic and deadly human coronaviruses, namely SARSCOV, MERS-CoV and SARS-CoV-2. The economic burden and health threats caused by these coronaviruses are extremely dreadful and getting more serious as the increasing number of global infections and attributed deaths of SARS-CoV-2 and MERS-CoV. Unfortunately, specific medical countermeasures for these hCoVs remain absent. Moreover, the fast spread of misinformation about the ongoing SARS-CoV-2 pandemic uniquely places the virus alongside an annoying infodemic and causes unnecessary worldwide panic. SARS-CoV-2 shares many similarities with SARS-COV and MERS-COV, certainly, obvious differences exist as well. Lessons learnt from SARS-CoV and MERSCoV, timely updated information of SARS-CoV-2 and MERS-CoV, and summarized specific knowledge of these hCoVs are extremely invaluable for effectively and efficiently contain the outbreak of SARS-CoV-2 and MERS-CoV. By gaining a deeper understanding of hCoVs and the illnesses caused by them, we can bridge knowledge gaps, provide cultural weapons for fighting and controling the spread of MERS-CoV and SARS-CoV-2, and prepare effective and robust defense lines against hCoVs that may emerge or reemerge in the future. To this end, the stateof-the-art knowledge and comparing the biological features of these lethal hCoVs and the clinical characteristics of illnesses caused by them are systematically summarized in the review.
\end{abstract}

Keywords: SARS-CoV, MERS-COV, SARS-CoV-2, IIIness, Biological features, Clinical characteristics

\section{Background}

Coronaviruses (CoVs) refer to a family of enveloped, positive-sense, single-stranded, and highly diverse RNA viruses [1]. There are four genera (alpha, beta, gamma, and delta), among which $\alpha$-coronavirus and $\beta$ coronavirus attract more attention because of their ability to cross animal-human barriers and emerge to

\footnotetext{
*Correspondence: gmarraro@picu.it; ymzeng08@163.com

'Zhixing Zhu and Xihua Lian are joint first author

'Department of Pulmonary and Critical Care Medicine, the Second Affiliated Hospital of Fujian Medical University, Respirology Medicine Centre of Fujian Province, 34 Zhongshanbei Road, Licheng District, Quanzhou, China Full list of author information is available at the end of the article
}

become major human pathogens [2]. So far, there are seven documented human coronaviruses (hCoVs), including the beta-genera CoVs, namely Severe Acute Respiratory Syndrome (SARS)-CoV (SARS-CoV), Middle East Respiratory Syndrome (MERS)-CoV (MERS-CoV), SARS-CoV hCoV-HKU1, and hCoV-OC43 and the $\alpha-$ genera CoVs, which are hCoV-NL63 and hCoV-229E, respectively $[1,3]$.

Although hCoV-HKU1, hCoV-OC43, hCoV-NL63 and hCoV-229E mainly cause asymptomatic or mild respiratory and gastrointestinal infections, they have been circulating in humans since they were recognized, and accounting for approximately $5-30 \%$ of common colds.

\section{$\triangle B M C$}

(c) The Author(s). 2020 Open Access This article is licensed under a Creative Commons Attribution 4.0 International License, which permits use, sharing, adaptation, distribution and reproduction in any medium or format, as long as you give appropriate credit to the original author(s) and the source, provide a link to the Creative Commons licence, and indicate if changes were made. The images or other third party material in this article are included in the article's Creative Commons licence, unless indicated otherwise in a credit line to the material. If material is not included in the article's Creative Commons licence and your intended use is not permitted by statutory regulation or exceeds the permitted use, you will need to obtain permission directly from the copyright holder. To view a copy of this licence, visit http://creativecommons.org/licenses/by/4.0/ The Creative Commons Public Domain Dedication waiver (http://creativecommons.org/publicdomain/zero/1.0/) applies to the data made available in this article, unless otherwise stated in a credit line to the data. 
Nonetheless, we have not treated hCoVs seriously until we witnessed the global epidemic caused by SARS-CoV and realized how devastating outcomes it brought to us [1]. To date, there have been three documented highly pathogenic and lethal hCoVs, namely SARS-CoV, MERS$\mathrm{CoV}$ and SARS-CoV-2, because of their dreadful impacts on humans [4]. Unlike other hCoVs, SARS-CoV, MERS$\mathrm{CoV}$, and SARS-CoV-2 are prone to infect the lower respiratory tract, resulting in acute lung injury (ALI)/acute respiratory distress syndrome (ARDS), septic shock and multi-organ failure, with high case fatality ratio (CFR) [5]. As shown in Table 1, SARS-CoV first emerged in Foshan, China in November 2002 [16], and was subsequently transported to Hong Kong in February 2003, from where it spread globally [10]. The epidemic was finally contained in July 2003 as the transmission chain of SARS-CoV in Taiwan was interrupted [10, 17]. There were four instances of SARS reemergence that occurred chronologically in Singapore, Taipei, Guangdong and Beijing afterwards [10, 18]. No more infected human cases have been reported since May 2004. However, another deathful hCoV emerges only a decade later. MERS-CoV first occurred in April 2012 in Jordan [19] and has been causing persistent endemics in countries within and sporadically spreading to countries outside the Middle East regions [13]. The most recent laboratory-confirmed patients were reported by Riyadh on 28 March 2020 [20]. SARS-CoV-2 has emerged while humans continue to be threatened by MERS-CoV [21]. SARS-CoV-2 first occurred in Wuhan, China in December 2019 and it swiftly spread across China and has been aggressively infecting people globally. It was documented as a public health emergency of international concern and a pandemic on 30 January and 11 March 2020, respectively, making SARS-CoV-2 the first $\mathrm{hCoV}$ to cause a pandemic [6, 7]. Uniquely, the recent ongoing pandemic is accompanied by an infodemic, which has caused additional worldwide panic [22].
Although these deadly hCoVs have been posing dreadful threats to humans [23], there are no medicines or vaccines available, which highlights the urgent need to gain a deeper understanding of these lethal hCoVs and the illnesses caused by them, and the importance of fighting an infodemic simultaneously [24]. Thus, we aim to briefly summarize the cutting-edge knowledge and to provide an update of the major features of SARS-CoV, MERS-CoV, and SARS-CoV-2 in terms of animal hosts, morphology and genome organization, cellular entry and viral transmission, and cytokine and chemokine responses. We have included the predominant characteristics of illnesses caused by these $\mathrm{hCoVs}$ with respect to demographic characteristics, incubation period and clinical manifestations, laboratory tests, imaging performance, and pulmonary pathology.

\section{Traits of SARS-CoV, MERS-CoV, and SARS-CoV-2}

\section{Animal hosts}

The potential animal hosts of SARS-CoV, MERS-CoV, and SARS-CoV-2 were summarized in Fig. 1. Notably, the outbreaks of these hCoVs are related to interactions between humans and animals, especially, both SARS$\mathrm{CoV}$ and SARS-CoV-2 emerge from wet markets in China. Considering early SARS patients were associated with wild animal markets in Guangdong, SARS-CoV was considered to emerge from wild animals (included palm civets) which were sold in these markets [16]. Subsequently, a strain of $\mathrm{CoV}$ shared highly homological similarity to SARS-CoV (99.8\%) was isolated from palm civets from wild animal markets, thus palm civetsderived CoVs were believed to be able to switch their hosts to human, causing the human-to-human transmission [25]. Additionally, the phenomenon that some SARS patients $(3 / 4)$ had had a clear contact history with

Table 1 The phylogenetic origin, crucial events and basic demographic information of SARS-CoV-2, SARS-CoV and MERS-CoV

\begin{tabular}{llll}
\hline & SARS-CoV-2[6-9] & SARS-CoV[10-12] & MERS-CoV[13-15] \\
\hline Genus & Clade I, lineage B & Clade I, lineage B & Clade II, lineage C \\
Length of nucleotides & 29.9 kilobases & 29.75 kilobases & 30.11 kilobases \\
First emergence & 7 December 2019, Wuhan, China & 16 November 2002, Foshan, China & 4 April 2012, Zarqa, Jordan \\
Virus identification & January 2020 & March 2003 & June 2012 \\
Causative agent declaration & January 2020 & April 2003 & September 2012 \\
Recent status & Pandemic ongoing & Completely control & Sporadic continuous \\
Number of infected cases & Above 12.7 million ${ }^{a}$ & 8096 & 2553 \\
Male-to-female ratio & $1.27: 1$ & $1: 1.13$ & $1.78: 1$ \\
Number of attributed deaths & Above 566 thousand ${ }^{a}$ & 774 & 876 \\
Number of viral Footprint & 213 countries or regions & 29 countries or regions & 27 countries or regions \\
Case fatal rate & $4.4 \%$ & $9.6 \%$ & $34.3 \%$ \\
\hline
\end{tabular}

NA Not available. ${ }^{a}$ According to the data released by the WTO on 13 , July, 2020 


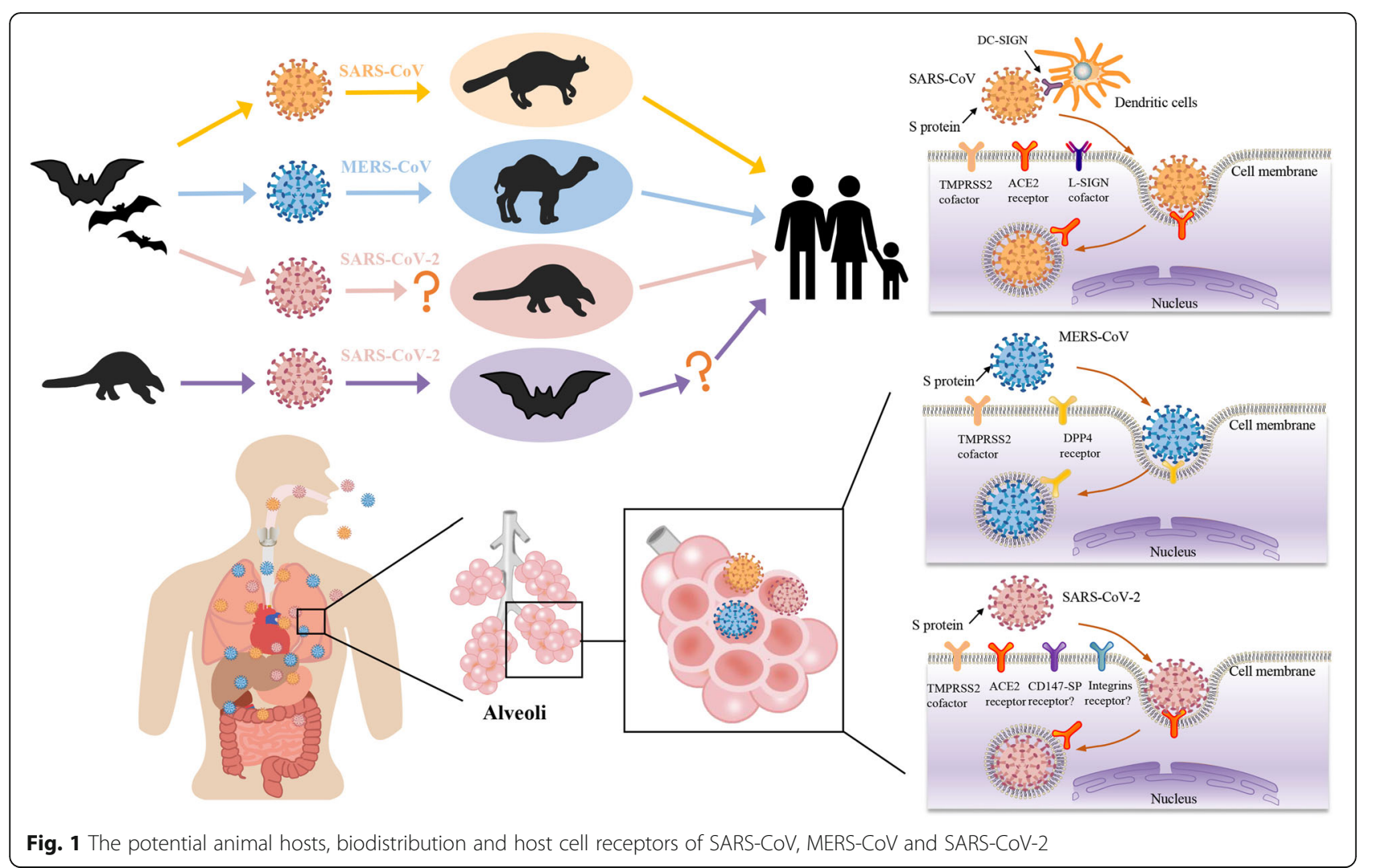

palm civets during the sporadic occurred in Guangdong was noticed, thereby epidemiologically supporting the previous assumption that palm civets act as important animal hosts of SARS-CoV [26]. Thus, it is reasonable to believe that palm civets were important intermediate hosts for SARS-CoV based on this strong evidence. Subsequently, scholars found that palm civets on farms are largely free from SARS-CoV infection while approximately $80 \%$ of the civets sold in an animal market were serologically positive (high level of SARS-CoV antibody), indicating that no widespread infection in wild civets [27]. Thus, palm civets became the intermediate hosts of SARS-CoV probably by getting infected during trade activities in or before reaching these wet markets [27, 28]. Afterwards, a strain of SARS-like-CoV was isolated from Chinese horseshoe bats, sharing $88-92 \%$ genomic identity to CoVs from humans or civet cats, strongly indicating that bats are natural hosts for SARS-CoV [29]. MERS-CoV is also believed to originate from bats [30]. The RNA fragment obtained by PCR amplification of nucleic acid isolated from bat stool shared 100\% nucleotide identity with MERS-CoV from an infected case living in the same area, indicating bats were probably the source for MERS-CoV [31]. Then, a bat-CoV was demonstrated to hold a close phylogenetic relationship with MERS-CoV [32]. Subsequently, the ability of replicating in bats without generating symptoms of MERS patients was demonstrated, suggesting that bats were ideal reservoirs for MERS-CoV [33]. The intermediate reservoir role of dromedary camels for MERS-CoV was supported by abundant evidence [34]. Two virological studies illustrated that MERS-CoV was circulating in dromedary camels and indicated potential cross-infection between them and humans. The high genomic identity of MERS$\mathrm{CoV}$ isolated from dromedary camels and humans was subsequently documented (99.2-99.5\%) [35, 36]. Afterward, the reservoir possibility and natural host-tohuman transmission role of dromedary camels were confirmed by several serological studies [37]. The origin of SARS-CoV-2 is more sophisticated. Similar to SARS$\mathrm{CoV}$, the emergence of SARS-CoV-2 was considered to be associated with trade activities in a wet market in Wuhan [21]. Researchers found that SARS-CoV-2 and BatCoV RaTG13 (a bat-CoV) were genetically similar and assumed that bats might be the natural reservoirs for SARS-CoV-2 [21]. Another study demonstrated that the similarity in genome between SARS-CoV-2 and the $\mathrm{CoV}$ isolated from pangolin (pangolin-CoV) was high but lower than that between SARS-CoV-2 and RaTG13 (91.02\% vs. $96.2 \%)$ [38]. These findings were echoed by two other research, in which their genomic similarity are 90.03 and $92.4 \%$, respectively [39, 40]. Scholars also analyzed the phylogenetic relationships among these CoVs, noticing that RaTG13 and SARS-CoV-2 were 
grouped together, and pangolin-CoV was their closest common ancestor. Taken together, Zhang et al. suggested that pangolin-CoV is another closely related kin of SARS-CoV-2, and pangolins rather than bats might be the natural reservoirs for SARS-CoV-2 and RaTG13 [38]. Although RaTG13 and SARS-CoV-2 share the highest homology regarding the overall genomic sequence, SARS-CoV-2 exhibits the highest sequence similarity $(97.4 \%)$ to pangolin-CoV in terms of receptorbinding domain (RBD), however, RBD sequence similarity between RaTG13 and SARS-CoV-2 is far less (89.2\%). More notably, six key RBD residues of SARS-CoV-2 and pangolin-CoV are completely identical while only one amino acid is the same between RaTG13 and SARSCoV-2 regarding these six residues [21]. These findings rendered the issue that which one is the natural reservoir remains controversial, nonetheless, it is agreed that there exists other animals acting as intermediate hosts [41]. A study speculated snakes are probably the intermediate hosts because a similar synonymous codon usage bias was found among SARS-CoV-2, a bat-derived SARSlike-CoV, and snakes [42]. However, their research is far from enough to make such a conclusion. Notably, there were several shortages in their study as described by Li J and colleagues [43]. More importantly, close relative synonymous codon usage alone is inadequate and cannot be used as reliable evidence to assume that snakes might serve as intermediate hosts for SARS-CoV-2.

\section{Morphology and genome organization}

Transmission electron microscopy images show that $\mathrm{CoVs}$ are spherical-shape viruses with spike proteins projecting from the virion surface, leaving themselves resemble solar crowns, therefore being termed "coronaviruses" [44]. Among RNA viruses, the genomic size of CoVs is only smaller than that of planarian secretory cell nidovirus (41 kilobases [kb]), ranging from 26 to $32 \mathrm{~kb}$ $[45,46]$. Of these deadly hCoVs, MERS-CoV has the largest genomic size (approximately $30.11 \mathrm{~kb}$ ), followed by SARS-CoV-2 and SARS-CoV, around $29.9 \mathrm{~kb}$ and 29.75 $\mathrm{kb}$, respectively [47]. SARS-CoV-2 shares approximately 79.5\% genomic homology with SARS-CoV while only about $50 \%$ similarity with MERS-CoV, indicating that SARS-CoV is closer to SARS-CoV [41]. These hCoVs all possess the typical genomic structure of betacoronaviruses, consisting of $5^{\prime}$ methylated caps and 3 ' polyadenylated tails [21, 48]. The 3 '-terminal region (one-third of the genome) is responsible for encoding structural proteins, namely spike protein, envelope protein, membrane protein, and nucleocapsid protein, which are critical for viral life cycle. The $5^{\prime}$-terminal region (twothirds) is the non-structural protein coding region, comprising significant genes, which are essential for viral replication [48, 49]. Genomic knowledge of hCoVs promotes the understanding of the origin and pathogenesis (host immune response and viral virulence and transmission mode) of hCoVs, thus, a better understanding of viral genomic information is crucial for combating the outbreaks of hCoVs by setting up precise strategies, such as developing diagnostic systems, potential drugs and vaccine candidates promptly [50].

\section{Cellular entry and viral transmission}

The spike protein not only acts as one of the requisite structural proteins of CoVs, but it also plays significant roles in the interaction between CoVs and host cells [51]. Structurally, spike protein consists of S1 and S2 subunit [51]. The RBD in the S1 subunit is responsible for viruses binding to host receptors and the S2 subunit is in charge of the fusion between viruses and host membranes, inducing the viral genome penetrates into host cells cytoplasm [52]. SARS-CoV, MERS-CoV and SARS-CoV-2 enter host cells are mediated by binding the receptor-binding domain to functional receptors on the host cell surface [53]. The angiotensin-converting enzyme 2 (ACE2) is the dominant host receptor of SARS-CoV [54]. DC-SIGN (CD209) and L-SIGN (CD209L) also function as co-receptors for SARS-CoV [55]. In contrast to ACE2, binding to DC-SIGN does not lead to SARS-CoV infection in dendritic cells but greatly enhances viral infection and dissemination. L-SIGN is also treated as an alternative receptor for SARS-CoV because L-SIGN can mediate cellular entry of SARS-CoV by binding to its spike protein [28].. The dipeptidyl peptidase 4 (DPP4, also termed CD26), is the cellular receptor for MERS-CoV [56]. Similarly, SARS-CoV-2 enters host cells by binding its spike protein to ACE2 [52, 53]. Importantly, ACE2 has a higher affinity to SARS-CoV-2 than to SARS-CoV [57]. Moreover, Christian et al. assumed that SARS-CoV-2 might alternatively use the integrins as cell receptors [58]. However, this assumption lacks strong experimental evidence. In contrast, stronger supporting evidence suggested that CD147-SP might be another entry route for SARS-CoV-2 [59]. Apart from the binding of spike proteins to functional receptors, the priming of spike proteins is also essential for hCoVs regarding cellular entry [60]. SARS-CoV, MERS-CoV and SARS-CoV-2 employ cellular serine protease TMPRSS2 and endosomal cysteine proteases cathepsin $\mathrm{B} / \mathrm{L}$ for spike protein priming, which is essential for them to enter host cells $[53,61]$. ACE2 has a vast biodistribution, including respiratory tract, gastrointestinal tract, heart, kidney and olfactory neuroepithelium $[62,63]$, besides these organs, DPP4 also expresses on liver, thymus, prostate and bone marrow [13], resulting in broad cellular and tissue tropisms of SARS-CoV, MERS-CoV, and SARS-CoV-2 [64-66]. Thus, these hCoVs can cause a wide range of symptoms, including 
respiratory manifestations and those beyond respiratory system to infected cases (described below), and their transmission routes are various as well. SARS-CoV-2 has the highest transmissibility, followed by SARS-CoV and MERS-CoV, of whom the basic reproductive number was projected to be $2-3.58,1.7-1.9$ and $<1$, respectively [67]. With the upsurge in the number of SARS-CoV-2 patients worldwide, its median basic reproductive number was projected at 5.7 [68]. SARS-CoV was mainly transmitted by a close person-to-person contact through inhaling air droplets or by contacting with contaminated surfaces of devices [69, 70]. A major community outbreak occurred in Hong Kong indicated that SARS-CoV probably could be transmitted by airborne [71]. Given another outbreak was attributed to fecal contamination, feco-oral transmission should not be ignored [72]. As for MERS-CoV, humans can be infected by contacting with infected dromedary camels [30]. Similarly, human-tohuman transmission is the major source of MERS-CoV transmission, however, MERS-CoV is not sustainably and frequently transmitted between humans [13]. Theoretically, MERS-CoV could also spread through contacting with stool, vomitus, urine, serum and cerebrospinal fluid of patients since MERS-CoV has been isolated from these samples [13]. Likewise, the key transmission path of SARS-CoV-2 is human-to-human transmission occurred in close contacts, predominantly spread by droplets and direct contact [73]. Besides, scarce and incomplete evidence indicates that maternal-fetal transmission of SARS-CoV-2 is likely possible but extremely rare [74]. Recently, researches showed that SARS-CoV-2 was detected in stool and its nucleocapsid protein was detected in gastrointestinal tissues, and live SARS-CoV-2 was cultivated from stool $[66,75,76]$. Notably, SARSCoV-2 could be detected in sputum, urine, blood/serum, ocular surface, saliva and aerosol as well [66, 75, 77-79]. Although the detection or cultivation of SARS-CoV-2 in these specimens does not firmly mean that SARS-CoV-2 is transmitted by these samples, we should be careful when we are dealing with these samples.

\section{Cytokine and chemokine responses}

A moderate cytokine and chemokine response plays an indispensable role in the viral clearance and subsequent recovery while dysregulated response can bring devastating outcomes to infected cases [80]. A large number of immune cells, including macrophages, neutrophils, monocytes and lymphocytes, are migrated from bloodstream to infection site by the recruitment of hyperactive cytokines and chemokines, resulting in further release of high concentrations of various cytokines and chemokines and activation of immune cells, thereby underlying the basis of immune-mediated damages to hosts [72, 81]. The ways that SARS-CoV, MERS-CoV and SARS-
CoV-2 cause histopathological injuries to infected cases are presented in Fig. 2. Briefly, these aforementioned hCoVs have been evolutionarily acquiring the ability to encode numerous proteins that allow them to evade from the host immune system, during which the delayed release of interferon plays a crucial role, then to attract and over-activate more inflammatory and immune cell, thereby inducing cytokine storm characterized by a massive secretion and hyper-activation of cytokines and chemokines until they have achieved sufficiently high titers $[1,80,82]$, and finally to cause severe injury of infected tissues [81, 83]. Supporting evidence is abundant. The crucial roles of exaggerated pro-inflammatory cytokine and chemokine response resulted from infections of SARS-CoV and MERS-CoV in the exacerbation of SARS and MERS illnesses were firmly demonstrated [84]. Specifically, the delayed but excessive production of cytokines and chemokines was thought to be the induction of dysregulated innate immune response to SARS-CoV infection and poor outcomes on the basis of the fact that elevated serum levels and prolonged response of proinflammatory cytokines and chemokines were observed in SARS patients and were associated with the severity of SARS-CoV infection [28, 81]. Similar phenomena have been observed in patients infected by MERS-CoV, especially those who were severely infected, among whom numerous cytokines and chemokines were excessively activated, massive inflammatory and immune cells were promptly attracted and infiltrated in infected tissues, resulting in severe immunological injuries or even death $[81,85]$. Likewise, the positive correlation between high pro-inflammatory cytokines and chemokines profile and the severity and outcomes of COVID-19 patients has been solidly confirmed, which indicates that SARSCoV-2 infection also leads to hypercytokinemia or cytokine storm, by which ALI or ARDS and extrapulmonary multiple-organ failure or even death occur in infected cases $[84,86]$. Similar to SARS, elevated levels of type 2 cytokines were also observed in COVID-19 [87, 88]. Although type 2 cytokines have anti-inflammation properties, and the expression of ACE2 was inhibited by them, surprisingly, they did not generate obvious benefits. This might be because type 2 cytokines simultaneously upregulated TMPRSS2 expression, which greatly negates their potential protective effects [89]. Overall, dysregulated cytokines and chemokines are associated with the progression and prognosis of infections caused by these hCoVs. Hence, interventions with these aberrant cytokines and chemokines might be promising for the managements of hCoVs-related diseases. Recently, many researchers are focused on the application of cytokine-based interventions, including immune inhibitors (such as inhibitors of IL-6, IFN- $\gamma$ and TNF- $\alpha$ ) in the therapy of COVID-19, and some of these inhibitors showed enthusiastic results 


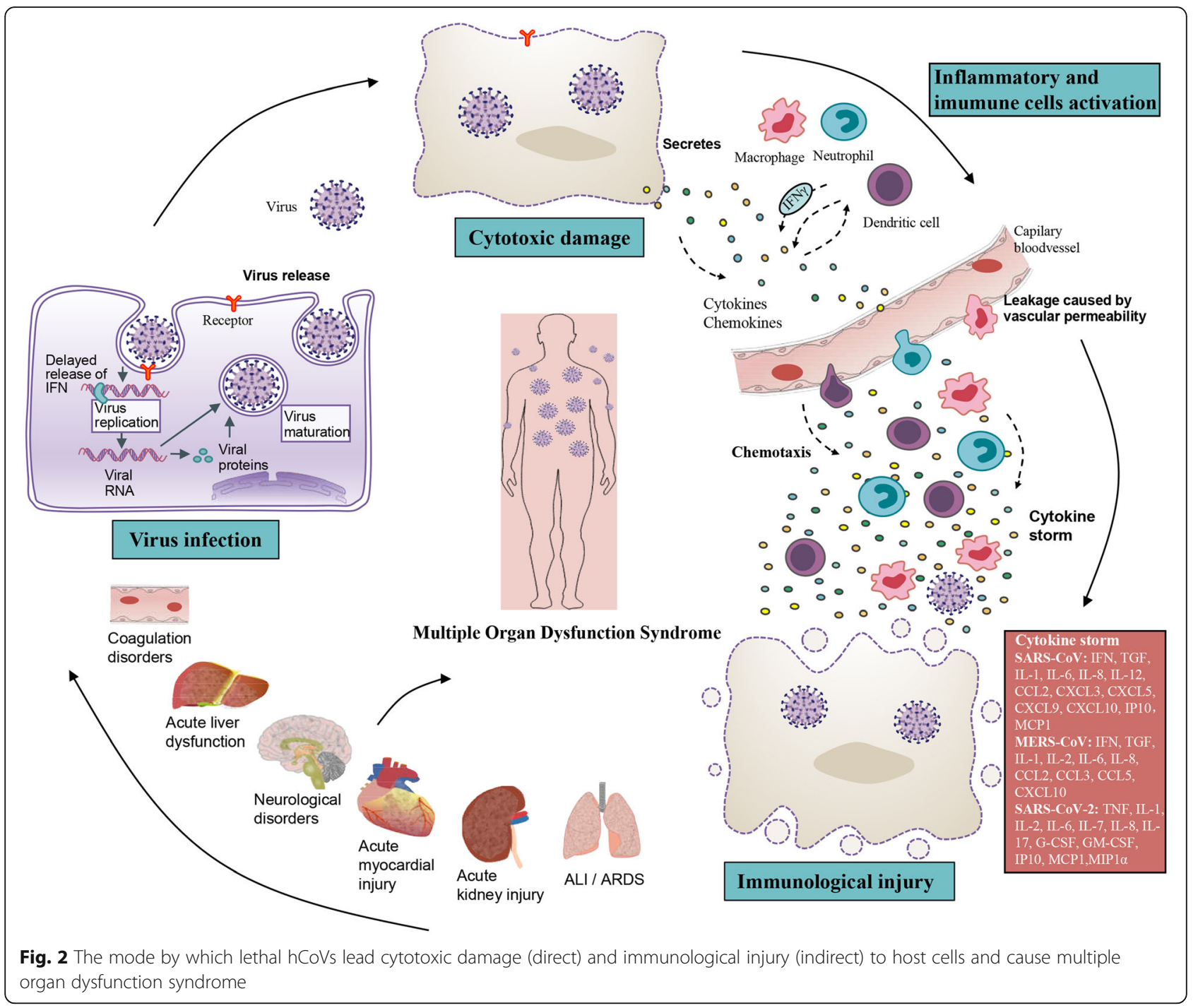

(such as IL-6 inhibitor, siltuximab) [90, 91], however, more studies are needed to further investigate the therapeutic effects of these inhibitors.

\section{Features of SARS, MERS and COVID-19}

\section{Demographic characteristics}

The majority of SARS cases were from China, Canada and Singapore, among which, cases from China mainland presented the largest proportion, followed by that from Hong Kong and Taiwan [11]. There was a female predominance (53\% vs. $47 \%$ ) [11]. Adult patients presented approximately $93 \%$ of infected cases while only $7 \%$ cases were children. The mean age was 39.9 years, with a range of 1 to 91 years [12]. Saudi Arabia population presented nearly $80 \%$ of MERS cases and around $91.0 \%$ of deaths, with a roughly CFR of $37.1 \%$, which nearly quadrupled that of SARS [14]. There was a sexual predisposition to male, while male patients presented
$64 \%$ of total patients, female patients only accounted for $36 \%$. The percentage of patients in adults was overwhelmingly surpassed that in children, which were 98 and $2 \%$, respectively. The median age was 50 years, with a range of 1 to 94 years [13, 15]. As for COVID-19, the numbers of infected cases and deaths keep increasing rapidly every day. As shown in Table 2, the numbers of patients, deaths and affected countries or regions have far exceeded those of SARS-CoV and MERS-CoV [8]. Similar to MERS, more patients were male, while male patients presented $55.9 \%$ of total cases, female patients only accounted for $44.1 \%$ [9]. Wu and colleagues showed that the age of most Chinese patients $(38,680 / 44672)$ ranged from 30 to 79 years [101]. The median age ranged from 34 to 63 years old according to different research [102-105]. Similarly, SARS-CoV-2 was less likely to infect children and adolescents [106]. Wu et al. reported that only $2.2 \%$ of 44,672 confirmed cases occurred in persons aged younger than 19 [101]; among 
Table 2 Clinical characteristics and laboratory findings of COVID-19, SARS and MERS patients

\begin{tabular}{|c|c|c|c|}
\hline & COVID-19 $[94,95,98]$ & SARS $[25,97-99]$ & MERS $[92,93,96,98,100]$ \\
\hline \multicolumn{4}{|l|}{ Signs and symptoms } \\
\hline Fever & $56-99 \%$ & $99-100 \%$ & $81.7-100 \%$ \\
\hline Fatigue & $18-55 \%$ & $31.2 \%$ & NA \\
\hline Cough & $39-81 \%$ & $29.0-74.3 \%$ & $75-85 \%$ \\
\hline Sore throat & $5-17 \%$ & $11.0-23.2 \%$ & 14 \\
\hline Dyspnea & $12-41 \%$ & $40-42 \%$ & $72 \%$ \\
\hline Myalgia & $18-55 \%$ & $49.3-60.9 \%$ & 38 \\
\hline Diarrhea & $3-17 \%$ & $20-25 \%$ & 26 \\
\hline Headache & $4-23 \%$ & $15.0-55.8 \%$ & NA \\
\hline \multicolumn{4}{|l|}{ Complications } \\
\hline ARDS & $18-30 \%$ & $20 \%$ & $20-30 \%$ \\
\hline AKI & $3 \%$ & $6.7 \%$ & $41-50 \%$ \\
\hline \multicolumn{4}{|l|}{ Laboratory findings } \\
\hline Leukopenia $\left(<4.0 \times 10^{9} / L\right)$ & $26.8 \%$ & $23-35 \%$ & $14 \%$ \\
\hline Lymphopenia $\left(<1.5 \times 10^{9} / \mathrm{L}\right)$ & $55.3 \%$ & $68-85 \%$ & $32 \%$ \\
\hline Thrombocytopenia $\left(<150 \times 10^{9} / L\right)$ & $11.5 \%$ & $40-45 \%$ & $36 \%$ \\
\hline Elevated LDH & $55.5 \%$ & $50-71 \%$ & $48 \%$ \\
\hline Elevated AST & $17.9 \%$ & $20-30 \%$ & $14 \%$ \\
\hline Elevated ALT & $16.0 \%$ & $20-30 \%$ & $11 \%$ \\
\hline
\end{tabular}

LDH Lactate dehydrogenase, AST Aspartate aminotransferase, ALT Alanine aminotransferase, NA Not available

149,082 cases reported by American CDC, only 1.7\% patients were aged younger than 18 [107]. Notably, among 1099 Chinese patients, only 10 cases $(0.9 \%)$ were younger than 15-year-old [103]. In contrast, the elderly not only are vulnerable to SARS-CoV-2, but they also are more susceptible to be severely infected by this hCoV; moreover, the senior population has higher CFR as well [101, 108, 109]. Although the reasons for the differences between young and senior generations are yet unclear, different expression levels of ACE2 and TMPRSS2 and different immune systems between them might be the possible explanations [106, 110], and the elderly have more comorbidities and senile immune systems might be the predominant factors.

\section{Incubation period and clinical manifestations}

During the incubation period, hCoVs will not cause overt clinical symptoms, but the knowledge of viral incubation period has significant applications in disease surveillance, prevention and control [111]. The median incubation period of SARS-CoV is 4 days (95\% CI 3.64.4) [111] and a longer one with $>10$ days was only observed in a small proportion of cases [112]. The median incubation period of MERS-CoV was 5.2 days (95\% CI 1.9-14.7) and the period could be longer in immunocompromised patients or those with comorbidities as well [13, 113]. The longest incubation period was 20 days and observed in a female who had received hematopoietic stem cell therapy after the recurrence of diffuse large B-cell lymphoma [113], which indicated that it is significant to evaluate the overall status of every suspicious or confirmed case when surveillance, prevention and control of infectious disease are carried out. While the incubation period of SARS-CoV-2 is yet unclear, it is estimated to be consistent with that of SARS$\mathrm{CoV}$ and MERS-CoV. The estimated median incubation period was consistent (4 days) but their interquartile ranges were various in three independent investigations (2-7 days, 3-6 days and 2.3-4.3 days, respectively) [103, $114,115]$. It could be longer, as reported by Lauer and colleagues, the estimate was 5.1 days (95\% CI, 4.5-5.8 days) [116]. Linton and colleagues showed that the mean incubation period was 5.0 days (95\% CI 4.2-6.0 days). This estimate was in line with a meta-analysis, showing that the pooled mean incubation period was 5.08 days (95\% CI 4.77-5.39 days) [117, 118]. Similarly, a longer estimate was also reported, which was 6.4 days (95\% CI 5.6-7.7 days) [119]. Recently, a pairwise comparison showed that there is no statistically significant difference in the incubation period among these three hCoVs [120]. In contrast, many pathological abnormalities emerge subsequence to hypercytokinemia or cytokine storm, including weakened stabilization of endothelial cell to cell interactions, damaged integrity of vascular barrier and capillary, diffused damage of alveolus, and multiple organs dysfunction [121], resulting in the onset 
of acute respiratory infections with systematic disorders after the incubation period [10, 13, 103, 122]. Hence, as shown in Table 2, although the clinical manifestations of SARS, MERS and COVID-19 are pretty similar, including fever $\left(\geq 38.0^{\circ} \mathrm{C}\right)$, cough, sore throat, dyspnea, headache, myalgia or fatigue, and diarrhea [99, 123, 124], patients would probably present a wide range of symptoms. The disease course of SARS is usually divided into two periods, namely the early period (1-7 days) and progress period (10-14 days). Usually, in the early period, SARS patients (except those started with dry cough) were additionally suffered from nonproductive cough 3 to 7 days after the occurrence of early symptoms; in progress period, patients' conditions obviously deteriorated, and some (10-20\%) ended with fatal outcome [10, 99]. MERS patients are usually manifested as severe respiratory infection once symptoms appeared and patients' condition progresses rapidly $[13,100]$. Significantly, acute kidney injury (AKI) is one atypical symptom of MERS patients, which promptly occurs in more than half of MERS cases after the viral incubation period (around a week) [92]. Compared with SARS patients, medical comorbidities include diabetes, hypertension, cardiovascular diseases, chronic renal failure and chronic pulmonary disease are more common in MERS patients, which partially account for the high CFR [93]. The clinical manifestations of COVID-19 are predominantly shared by SARS and MERS [94, 103]. Apart from diarrhea, other gastrointestinal symptoms, including nausea and vomiting are common in COVID-19 patients as well [125]. COVID-19 patients predominantly present with mild symptoms, but those with comorbidities have worse clinical outcomes [126]. Although the previous CFR of COVID-19 was far less than that of its counterparts, the CFR of COVID-19 has gradually increased as the mounting number of deaths worldwide [8, 11, 14]. Additionally, there are asymptomatic patients as well. Although these cases were asymptomatic, they can disseminate hCoVs, thereby posing a great challenge to infection control. Thus, it is of great significance to better understand the aspect of these hCoVs, however, asymptomatic case rate is difficult to estimate. To date, the estimated asymptomatic infections incidence various in different research. Worse still, these cases reported in these investigations only presented the tip of the iceberg, and the true rates remain unclear [118, 127-129].

\section{Laboratory tests}

Molecular tests such as polymerase chain reaction using viral RNA extracted from clinical samples have become the standard and primary diagnostic test of SARS, MERS and COVID-19 due to its high sensitivity, specificity and simplicity $[122,130]$. However, the sensitivity of serology tests such as antibody detection was generally lower than that of molecular tests and antibody detection was predominantly used in retrospective diagnosis for SARS and MERS [93]. Similarly, the slow plasma antibody responses to SARS-CoV-2 were confirmed, however, serological assay remains significant for the diagnosis and management of COVID-19 because the combination of antibody test greatly increased the sensitivity of viral RNA detection in the diagnosis of SARS-CoV-2 [131]. As presented in Table 2, the laboratory findings of SARS, MERS and COVID-19 patients are greatly similar, of whom the commonest abnormal laboratory findings are lymphocytopenia and thrombocytopenia. In addition, the serum levels of lactate dehydrogenase, aspartate aminotransferase, alanine aminotransferase and C-reactive protein are significantly elevated [95-97]. Coagulation disorders characterized by elevated D-dimer level and prolonged prothrombin time are common, especially in severe patients [98]. Meanwhile, elevated level of creatine kinase and serum creatinine in diverse degrees were commonly found in some patients, especially in MERS patients [95-97].

\section{Chest radiology}

The imaging performance of viral pneumonia is almost overlapping, however, some specific differences exist as well. Although the chest X-ray/CT performance of pneumonia caused by SARS-CoV, MERE-CoV, and SARS-CoV-2 are similar, chest CT is preferred due to its high resolution, sensitivity and efficacy. As shown in Table 3, the commonest chest radiological performance of SARS, MERS and COVID-19 patients is multifocal or mixed ground-glass opacities, or crazy paving pattern in some cases, followed by consolidation, smooth or irregular interlobular septal thickening and air bronchogram [132-137]. Pleural effusion is rare or only occurs in severe SARS and COVID-19 patients, while it is common in MERS cases (roughly 33-50\%). Pneumothorax and centrilobular nodules can be detected only in a few patients, whilst cavitation and lymphadenopathy are both rare or absent. Notably, in most COVID-19 cases, both lungs (multiple lobes, especially the lower lobes are involved) are simultaneously infected by SARS-CoV-2, exhibiting peripheral distribution on chest CT images, nonetheless, in the initial period of SARS and MERS, lungs are more commonly involved in unilateral or unifocal than multifocal involvement. Recently, PET/CT has been developed to image and measure lung inflammation [138]. A COVID-19 case series research demonstrated that pulmonary peripheral ground-glass opacities and lung consolidations are characterized by a high ${ }^{18} \mathrm{~F}$ FDG uptake and lymph node involvement was supported by PET/CT examination [139]. Lung ultrasound has recently become a reliable and convenient technique, playing an auxiliary role in diagnosing and evaluating 
Table 3 Chest X-ray/CT features of COVID-19, SARS and MERS patients

\begin{tabular}{|c|c|c|c|}
\hline & COVID-19 [132, 133] & SARS $[134,135]$ & MERS $[136,137]$ \\
\hline Image performance & $\begin{array}{l}\text { Bilateral, multifocal, peripheral } \\
\text { distribution }\end{array}$ & $\begin{array}{l}\text { Unilateral, focal; unilateral, multifocal; bilateral; } \\
\text { peripheral distribution }\end{array}$ & $\begin{array}{l}\text { Bilateral, multifocal; isolated unilateral; } \\
\text { peripheral distribution }\end{array}$ \\
\hline Normal radiography & $19.90 \%$ & $18.40 \%$ & $20.00 \%$ \\
\hline \multicolumn{4}{|l|}{ Abnormal radiography } \\
\hline $\begin{array}{l}\text { Ground-glass } \\
\text { opacities }\end{array}$ & $68.92 \%$ & $68.48 \%$ & $86.36 \%$ \\
\hline Crazy paving pattern & $8.56 \%$ & $46.27 \%$ & $26.67 \%$ \\
\hline Consolidation & $26.64 \%$ & $65.65 \%$ & $50.00 \%$ \\
\hline $\begin{array}{l}\text { Interlobular septal } \\
\text { thickening }\end{array}$ & $34.54 \%$ & $55.22 \%$ & $40.91 \%$ \\
\hline Air bronchogram & $34.54 \%$ & $37.04 \%$ & NA \\
\hline Pleural effusion & $3.57 \%$ & $17.31 \%$ & $54.55 \%$ \\
\hline Pneumothorax & Rare & $9.62 \%$ & Rare \\
\hline $\begin{array}{l}\text { Centrilobular } \\
\text { nodules }\end{array}$ & Not seen & Not seen & Not seen \\
\hline Cavitation & Not seen & Not seen & Not seen \\
\hline Lymphadenopathy & $6.00 \%$ & Not seen & Not seen \\
\hline
\end{tabular}

$N A$ not available

the severity of respiratory diseases, such as interstitial lung disease, ARDS, acute pulmonary edema, and pneumonia pleural effusion, pneumothorax, atelectasis, and pulmonary embolism [140, 141]. Besides, lung ultrasound contributes to the diagnosis and severity assessment of COVID-19. The main ultrasonic signs of COVID-19 are bilateral thickening and irregular pleural line; various patterns of B-line including focal, multifocal and confluent; various patterns of consolidations including small and translobar with or without mobile air bronchograms. Besides, pleural effusion can be detected in some patients as well, but it is rare [142, 143].

\section{Pulmonary pathology}

As shown in Table 4, pulmonary histopathological abnormalities of SARS, MERS and COVID-19 cases are non-specific. These changes result from direct viral cytotoxic and immunopathogenic effects. They are mainly characterized by diffuse alveolar damage (DAD), which includes two categories, namely acute exudative DAD and proliferative DAD. Several SARS autopsy research showed that SARS-CoV could damage multiple tissues, however, the major histopathology involves lungs $[55,150,151]$. Different traits of DAD were observed during different disease stages [152]. Specifically, acute exudative DAD is the predominant pulmonary pathology finding of early period SARS. Besides, proliferative DAD was additionally observed in the progress period. Notably, with the extension of illness duration (over 2-3 weeks), the organizing and proliferative features of DAD became obvious while the exudative traits of DAD were rarely seen $[55,153,154]$. Similarly, DAD is the predominant pathological feature of MERS based on autopsy investigations of MERS [13, 155, 156]. Besides,

Table 4 Pulmonary pathology of COVID-19, SARS, and MERS

\begin{tabular}{|c|c|c|c|}
\hline & COVID-19[144-149] & SARS[55, 150-154] & MERS [13, 155-158] \\
\hline $\begin{array}{l}\text { Gross } \\
\text { examination }\end{array}$ & $\begin{array}{l}\text { Diffuse congestions with partly hemorrhagic } \\
\text { necrosis }\end{array}$ & $\begin{array}{l}\text { Edematous lungs with diffuse congestion, } \\
\text { enlarge pulmonary hila lymph nodes, irregular } \\
\text { and patchy consolidation areas }\end{array}$ & Edematous lungs with consolidation \\
\hline $\begin{array}{l}\text { Microscopic } \\
\text { manifestation }\end{array}$ & $\begin{array}{l}\text { Main abnormalities: } 1 \text {. Early-stage: exudative } \\
\text { DAD without hyaline membrane formation; } 2 \text {. } \\
\text { Advanced-stage: DAD with hyaline membrane } \\
\text { formation; } \\
\text { Others: pleural effusion and adhesion, mucous } \\
\text { plugs formation, macrophages, neutrophils } \\
\text { and lymphocytes infiltration; microvascular } \\
\text { injury (microthrombi) }\end{array}$ & $\begin{array}{l}\text { Main abnormalities: 1. Acute-period: acute ex- } \\
\text { udative DAD (extensive edema and hyaline } \\
\text { membrane formation, alveolar epithelial cells } \\
\text { impairment, alveoli collapse, and fibrous tissue } \\
\text { in alveolar spaces); } 2 \text {. Progress-period: Combin- } \\
\text { ation of acute exudative DAD and proliferative } \\
\text { DAD (fibrinous interstitial and airspace and hy- } \\
\text { perplastic pneumocytes); } \\
\text { Others: intravascular microthrombi }\end{array}$ & $\begin{array}{l}\text { Main abnormalities: Acute exudative } \\
\text { DAD with focal hemorrhagic } \\
\text { necrotizing pneumonia (dispersed } \\
\text { necrotic debris); } \\
\text { Others: NA }\end{array}$ \\
\hline Superinfection & Bacteria & Bacteria, fungi, viruses & NA \\
\hline
\end{tabular}


focal hemorrhagic necrotizing pneumonia was also observed in MERS cases [156]. Considering autopsy studies were rarely performed, some experiments were carried out, of which the findings were consistent with that observed in humans [157, 158]. The major pulmonary histological performance of COVID-19 greatly resembled those of SARS and MERS, but differences exist as well. Similar to SARS, the microscopic manifestations of COVID-19 are different in different stages of illness $[55,144,145]$. The major pathology manifestations of COVID-19 include bilateral DAD as well as interstitial inflammation and fibrosis [146, 147]. Pleural lesions, mucous plugs and inflammatory cell infiltration were observed [148]. Whether hyaline membrane formation in infected lungs remains controversial in different research. Tian and colleagues compared the differences of histological features between early-stage COVID-19 and advanced-stage COVID-19 and declared that the formation of hyaline membrane might be a pathological characteristic of advanced-stage COVID-19 [144, 145]. Notably, intravascular microthrombi were found in patients with SARS and COVID-19 [55, 149, 153], and the combination of DAD and thrombosis contributed to the rapid deterioration of clinical conditions in severe COVID-19 cases [152].

\section{Conclusion}

Although there are many similarities among SARS-CoV, MERS-CoV, and SARS-CoV-2 and severe illnesses cause by them, these lethal hCoVs and illnesses are characterized by distinctive traits. The periodical emergence of highly pathogenic $\mathrm{hCoV}$ has been sustainably posing heavy burden and threat to humans. Though some drugs were thought to be promising candidates for COVID-19 therapy, they were experimentally labeled as inefficient because of lacking therapeutic effects with statistical importance or reasonably satisfactory clinical outcomes [159], thus, approval medicines remain absent so far, and vaccines either. What should bear in mind is that MERS-CoV remains circulates [13] and the number of SARS-CoV-2 infected cases and deaths continues climbing quickly and the fast spread of SARS-CoV-2 attributed infodemic has been causing unnecessary panic globally. Thus, more research are urgently needed to unveil the secrets of these deadly hCoVs and related infections, especially in developing specific medicine and vaccines, and effective interventions should be prepared in case of the emerge or reemerge of hCoVs in the future as well, thereby minimizing the burden and threat resulted from the infections and spreads of hCoVs.

\section{Abbreviations}

CoVs: Coronaviruses; hCoVs: Human coronaviruses; SARS: Severe Acute Respiratory Syndrome; MERS: Middle East Respiratory Syndrome; COVID-

19: Coronavirus Disease 2019; ALl: Acute lung injury; ARDS: Acute respiratory distress syndrome; AKl: Acute kidney injury; CFR: Case fatality ratio; WHO: World Health Organization; ACE2: Angiotensin-converting enzyme 2; DPP4: Dipeptidyl peptidase 4; DAD: Diffuse alveolar damage.

\section{Acknowledgements}

Grammar proofread of this paper was provided by Professor Dachun Wang of Pulmonary Center of Excellence, University of Texas Health Science Center at Houston, Houston, Texas, USA. We are also appreciative of the proofing from Naping Qiu who teaches English in a famous public high school in Shanghai, China.

\section{Authors' contributions}

YMZ and GAM conceived the study. ZXZ and XHL analyzed the data. XHL, XSS and WJW created the figures and tables. ZXZ, XHL and XSS wrote the first draft. ZXZ and WJW edited the paper. ZXZ, YMZ and GAM critically reviewed the paper. All authors discussed the results and contributed to the final manuscript.

\section{Funding}

This research was sponsored by the Research Project of Science and Technology Department of Fujian Province, China (2018 J01288), the Youth Research Project of Health and Family Planning Commission of Fujian Province, China (2018-1-62 and 2018-2-23), Quanzhou Science and Technology Project (2018 N012), the Research Project of Collaborative Innovation Center for Maternal and Infant Health Service Application Technology (XJM1802) and the National Key Research and Development Program of China (2016YFC1304).

Availability of data and materials

Not applicable.

Ethics approval and consent to participate

Not applicable.

Consent for publication

Not applicable.

\section{Competing interests}

The authors declare that they have no competing interests.

\section{Author details}

'Department of Pulmonary and Critical Care Medicine, the Second Affiliated Hospital of Fujian Medical University, Respirology Medicine Centre of Fujian Province, 34 Zhongshanbei Road, Licheng District, Quanzhou, China.

${ }^{2}$ Department of Ultrasound Medicine, the Second Affiliated Hospital of Fujian Medical University, 34 Zhongshanbei Road, Licheng District, Quanzhou, China. ${ }^{3}$ Healthcare Accountability Lab, University of Milan, Via Festa Del Perdono, Milan, Italy.

Received: 24 April 2020 Accepted: 2 August 2020

Published online: 27 August 2020

\section{References}

1. Weiss SR. Forty years with coronaviruses. J Exp Med. 2020;217:e20200537.

2. Coleman CM, Frieman MB. Coronaviruses: important emerging human pathogens. J Virol. 2014;88:5209-12.

3. Coronaviridae Study Group of the International Committee on Taxonomy of Viruses. The species Severe acute respiratory syndrome-related coronavirus: classifying 2019-nCoV and naming it SARS-CoV-2. Nat Microbiol. 2020;5:53644.

4. Meo SA, Alhowikan AM, Al-Khlaiwi T, Meo IM, Halepoto DM, Iqbal M, Usmani AM, Hajjar W, Ahmed N. Novel coronavirus 2019-nCoV: prevalence, biological and clinical characteristics comparison with SARS-CoV and MERSCoV. Eur Rev Med Pharmacol Sci. 2020;24:2012-9.

5. Vos LM, Bruyndonckx R, Zuithoff NPA, Little P, Oosterheert JJ, Broekhuizen BDL, Lammens C, Loens K, Viveen M, Butler CC, et al. Lower respiratory tract infection in the community: associations between viral aetiology and illness course. Clin Microbiol Infect. 2020;S1198-743X(20)30168-3.

6. World Health Organization.Statement on the second meeting of the International Health Regulations (2005) Emergency Committee regarding the outbreak of novel coronavirus (2019-nCoV). 2020. https://www.who.int/ 
news-room/detail/30-01-2020-statement-on-the-second-meeting-of-theinternational-health-regulations-(2005)-emergency-committee-regardingthe-outbreak-of-novel-coronavirus-(2019-ncov ). Accessed 13 July 2020.

7. World Health Organization. WHO Director-General's opening remarks at the media briefing on COVID-19 - 11 March 2020. 2020. https://www.who.int/ dg/speeches/detail/who-director-general-s-opening-remarks-at-the-mediabriefing-on-covid-19\%2D\%2D-11-march-2020. Accessed 13 July 2020.

8. World Health Organization. Coronavirus disease 2019 (COVID-19) Situation Report - 175. 2020. https://www.who.int/docs/default-source/coronaviruse/ situation-reports/20200423-sitrep-94-covid-19.pdf?sfvrsn=b8304bf0_4. Accessed 13 July 2020.

9. Rodriguez-Morales AJ, Cardona-Ospina JA, Gutierrez-Ocampo E, VillamizarPena R, Holguin-Rivera Y, Escalera-Antezana JP, Alvarado-Arnez LE, BonillaAldana DK, Franco-Paredes C, Henao-Martinez AF, et al. Clinical, laboratory and imaging features of COVID-19: a systematic review and meta-analysis. Travel Med Infect Dis. 2020;34:101623.

10. Hui DSC, Zumla A. Severe acute respiratory syndrome: historical, epidemiologic, and clinical features. Infect Dis Clin N Am. 2019;33:869-89.

11. World Health Organization. Summary of probable SARS cases with onset of illness from 1 November 2002 to 31 July 2003. 2003. https://www.who.int/ csr/don/2003_07_05/en/. Accessed 13 July 2020.

12. Leung GM, Hedley AJ, Ho LM, Chau P, Wong IO, Thach TQ, Ghani AC, Donnelly CA, Fraser C, Riley S, et al. The epidemiology of severe acute respiratory syndrome in the 2003 Hong Kong epidemic: an analysis of all 1755 patients. Ann Intern Med. 2004;141:662-73.

13. Memish ZA, Perlman S, Van Kerkhove MD, Zumla A. Middle East respiratory syndrome. Lancet. 2020;395:1063-77.

14. World Health Organization. MERS situation update, January 2020. 2020. http://www.emro.who.int/pandemic-epidemic-diseases/mers-cov/merssituation-update-january-2020.html. Accessed 13 July 2020.

15. Azhar El, Hui DSC, Memish ZA, Drosten C, Zumla A. The Middle East respiratory syndrome (MERS). Infect Dis Clin N Am. 2019;33:891-905.

16. Zhong NS, Zheng BJ, Li YM, Poon XZH, Chan KH, Li PH, Tan SY, Chang Q, Xie JP, et al. Epidemiology and cause of severe acute respiratory syndrome (SARS) in Guangdong, People's Republic of China, in February, 2003. Lancet. 2003:362:1353-8.

17. World Health Organization. Update 96 - Taiwan, China: SARS transmission interrupted in last outbreak area. 2003. https://www.who.int/csr/don/2003 07_05/en/. Accessed 13 July 2020.

18. Cherry JD. The chronology of the 2002-2003 SARS mini pandemic. Paediatr Respir Rev. 2004;5:262-9.

19. Hijawi B, Abdallat M, Sayaydeh A, Alqasrawi S, Haddadin A, Jaarour N, Alsheikh S, Alsanouri T. Novel coronavirus infections in Jordan, April 2012: epidemiological findings from a retrospective investigation. East Mediterr Health J. 2013;19(Suppl 1):S12-8.

20. World Health Organization. Middle East respiratory syndrome coronavirus (MERS-CoV) - The Kingdom of Saudi Arabia. 2020. https://www.who.int/csr/ don/08-april-2020-mers-saudi-arabia/en/. Accessed 13 July 2020.

21. Zhou $P$, Yang $X L$, Wang $X G$, Hu B, Zhang L, Zhang W, Si HR, Zhu Y, Li B, Huang $C L$, et al. A pneumonia outbreak associated with a new coronavirus of probable bat origin. Nature. 2020;579:270-3.

22. World Health Organization. COVID-19: Infodemic spreads faster than pandemic. 2020. https://www.aa.com.tr/en/latest-on-coronavirus-outbreak/ covid-19-infodemic-spreads-faster-than-pandemic/1786381. Accessed 13 July 2020.

23. Peeri NC, Shrestha N, Rahman MS, Zaki R, Tan Z, Bibi S, Baghbanzadeh M, Aghamohammadi N, Zhang W, Haque U. The SARS, MERS and novel coronavirus (COVID-19) epidemics, the newest and biggest global health threats: what lessons have we learned? Int J Epidemiol. 2020:49:717-26.

24. Zarocostas J. How to fight an infodemic. Lancet. 2020;395:676.

25. Guan Y, Zheng BJ, He YQ, Liu XL, Zhuang ZX, Cheung CL, Luo SW, Li PH, Zhang LJ, Guan YJ, et al. Isolation and characterization of viruses related to the SARS coronavirus from animals in southern China. Science. 2003;302:276-8.

26. Wang $M$, Yan $M, X u H$, Liang $W$, Kan $B$, Zheng $B$, Chen $H$, Zheng $H, X u$,

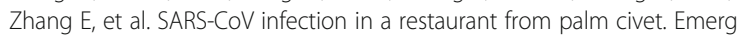
Infect Dis. 2005;11:1860-5.

27. Tu C, Crameri G, Kong X, Chen J, Sun Y, Yu M, Xiang H, Xia X, Liu S, Ren T, et al. Antibodies to SARS coronavirus in civets. Emerg Infect Dis. 2004;10: 2244-8.

28. Chen J, Subbarao K. The Immunobiology of SARS*. Annu Rev Immunol, 2007;25:443-72.
29. Ren W, Li W, Yu M, Hao P, Zhang Y, Zhou P, Zhang S, Zhao G, Zhong Y, Wang $S$, et al. Full-length genome sequences of two SARS-like coronaviruses in horseshoe bats and genetic variation analysis. J Gen Virol. 2006:87:3355-9.

30. Killerby ME, Biggs HM, Midgley CM, Gerber SI, Watson JT. Middle East respiratory syndrome coronavirus transmission. Emerg Infect Dis. 2020;26: 191-8.

31. Memish ZA, Mishra N, Olival KJ, Fagbo SF, Kapoor V, Epstein JH, Alhakeem R, Durosinloun A, Al Asmari M, Islam A, et al. Middle East respiratory syndrome coronavirus in bats, Saudi Arabia. Emerg Infect Dis. 2013;19:1819-23.

32. Ge XY, Li JL, Yang XL, Chmura AA, Zhu G, Epstein JH, Mazet JK, Hu B, Zhang $W$, Peng $C$, et al. Isolation and characterization of a bat SARS-like coronavirus that uses the ACE2 receptor. Nature. 2013;503:535-8.

33. Munster VJ, Adney DR, van Doremalen N, Brown VR, Miazgowicz KL, MilnePrice S, Bushmaker T, Rosenke R, Scott D, Hawkinson A, et al. Replication and shedding of MERS-CoV in Jamaican fruit bats (Artibeus jamaicensis). Sci Rep. 2016;6:21878.

34. Shalhoub S, Omrani AS. Middle East respiratory syndrome. BMJ. 2016;355: i5281.

35. Azhar El, El-Kafrawy SA, Farraj SA, Hassan AM, Al-Saeed MS, Hashem AM, Madani TA. Evidence for camel-to-human transmission of MERS coronavirus. N Engl J Med. 2014;370:2499-505.

36. Raj VS, Farag EA, Reusken CB, Lamers MM, Pas SD, Voermans J, Smits SL, Osterhaus AD, Al-Mawlawi N, Al-Romaihi HE, et al. Isolation of MERS coronavirus from a dromedary camel, Qatar, 2014. Emerg Infect Dis. 2014;20: 1339-42.

37. Chu DK, Poon LL, Gomaa MM, Shehata MM, Perera RA, Abu Zeid D, El Rifay AS, Siu LY, Guan Y, Webby RJ, et al. MERS coronaviruses in dromedary camels, Egypt. Emerg Infect Dis. 2014;20:1049-53.

38. Zhang T, Wu Q, Zhang Z. Probable Pangolin Origin of SARS-CoV-2 Associated with the COVID-19 Outbreak. Curr Biol. 2020;30:1346-51.

39. Lam TT, Shum MH, Zhu HC, Tong YG, Ni XB, Liao YS, Wei W, Cheung WY, Li WJ, Li LF, et al. Identifying SARS-CoV-2 related coronaviruses in Malayan pangolins. Nature. 2020;583:282-5.

40. Xiao K, Zhai J, Feng Y, Zhou N, Zhang X, Zou J-J, Li N, Guo Y, Li X, Shen X, et al. Isolation and Characterization of 2019-nCoV-like Coronavirus from Malayan Pangolins. bioRxiv. 2020; 2020.2002.2017.951335.

41. Lu R, Zhao X, Li J, Niu P, Yang B, Wu H, Wang W, Song H, Huang B, Zhu N, et al. Genomic characterisation and epidemiology of 2019 novel coronavirus: implications for virus origins and receptor binding. Lancet. 2020;395:565-74.

42. Ji W, Wang W, Zhao X, Zai J, Li X. Cross-species transmission of the newly identified coronavirus 2019-nCoV. J Med Virol. 2020;92:433-40.

43. Qian J, Feng Y, Li J. Comments on "cross-species transmission of the newly identified coronavirus 2019-nCoV". J Med Virol. 2020;10.1002/jmv.25983.

44. Ashour HM, Elkhatib WF, Rahman MM, Elshabrawy HA. Insights into the Recent 2019 Novel coronavirus (SARS-CoV-2) in light of past human coronavirus outbreaks. Pathogens. 2020;9:186.

45. Su S, Wong G, Shi W, Liu J, Lai ACK, Zhou J, Liu W, Bi Y, Gao GF. Epidemiology, genetic recombination, and pathogenesis of coronaviruses. Trends Microbiol. 2016:24:490-502.

46. Saberi A, Gulyaeva AA, Brubacher JL, Newmark PA, Gorbalenya AE. A planarian nidovirus expands the limits of RNA genome size. PLoS Pathog. 2018;14:e1007314.

47. Al-Qahtani AA. Severe acute respiratory syndrome coronavirus 2 (SARS-CoV2): emergence, History, Basic and Clinical Aspects. Saudi J Biol Sci. 2020;10. 1016/j.sjbs.2020.04.033.

48. Yang D, Leibowitz JL. The structure and functions of coronavirus genomic $3^{\prime}$ and 5' ends. Virus Res. 2015;206:120-33.

49. Wu A, Peng Y, Huang B, Ding X, Wang X, Niu P, Meng J, Zhu Z, Zhang Z, Wang J, et al. Genome composition and divergence of the novel coronavirus (2019-nCoV) originating in China. Cell Host Microbe. 2020;27:325-8.

50. Llanes A, Restrepo CM, Caballero Z, Rajeev S, Kennedy MA, Lleonart R. Betacoronavirus genomes: how genomic information has been used to Deal with past outbreaks and the COVID-19 pandemic. Int J Mol Sci. 2020; 21:4546.

51. Schoeman D, Fielding BC. Coronavirus envelope protein: current knowledge. Virol J. 2019;16:69.

52. Ou X, Liu Y, Lei X, Li P, Mi D, Ren L, Guo L, Guo R, Chen T, Hu J, et al. Characterization of spike glycoprotein of SARS-CoV-2 on virus entry and its immune cross-reactivity with SARS-CoV. Nat Commun. 2020;11:1620. 
53. Hoffmann M, Kleine-Weber H, Schroeder $\mathrm{S}$, Krüger N, Herrler T, Erichsen S, Schiergens TS, Herrler G, Wu NH, Nitsche A, et al. SARS-CoV-2 Cell Entry Depends on ACE2 and TMPRSS2 and Is Blocked by a Clinically Proven Protease Inhibitor. Cell. 2020;181:271-80.

54. Li W, Moore MJ, Vasilieva N, Sui J, Wong SK, Berne MA, Somasundaran M, Sullivan JL, Luzuriaga K, Greenough TC, et al. Angiotensin-converting enzyme 2 is a functional receptor for the SARS coronavirus. Nature. 2003; 426:450-4.

55. Gu J, Korteweg C. Pathology and pathogenesis of severe acute respiratory syndrome. Am J Pathol. 2007;170:1136-47.

56. Lu G, Hu Y, Wang Q, Qi J, Gao F, Li Y, Zhang Y, Zhang W, Yuan Y, Bao J, et al. Molecular basis of binding between novel human coronavirus MERSCoV and its receptor CD26. Nature. 2013;500:227-31.

57. Wrapp D, Wang N, Corbett KS, Goldsmith JA, Hsieh CL, Abiona O, Graham BS, McLellan JS. Cryo-EM structure of the 2019-nCoV spike in the prefusion conformation. Science. 2020;367:1260-3.

58. Sigrist CJ, Bridge A, Le Mercier P. A potential role for integrins in host cell entry by SARS-CoV-2. Antivir Res. 2020;177:104759.

59. Wang K, Chen W, Zhou Y-S, Lian J-Q, Zhang Z, Du P, Gong L, Zhang Y, Cui $\mathrm{H}-\mathrm{Y}$, Geng J-J, et al. SARS-CoV-2 invades host cells via a novel route: CD147spike protein. bioRxiv. 2020; 2020.2003.2014.988345.

60. Cui J, Li F, Shi ZL. Origin and evolution of pathogenic coronaviruses. Nat Rev Microbiol. 2019;17:181-92.

61. Hoffmann M, Kleine-Weber H, Pöhlmann S. A Multibasic Cleavage Site in the Spike Protein of SARS-CoV-2 Is Essential for Infection of Human Lung Cells. Mol Cell. 2020;78:779-84.

62. Imai Y, Kuba K, Ohto-Nakanishi T, Penninger JM. Angiotensin-converting enzyme 2 (ACE2) in disease pathogenesis. Circ J. 2010;74:405-10.

63. Fodoulian L, Tuberosa J, Rossier D, Landis BN, Carleton A, Rodriguez I. SARSCoV-2 receptor and entry genes are expressed by sustentacular cells in the human olfactory neuroepithelium. bioRxiv. 2020. https://doi.org/10.1101/ 2020.03.31.013268.

64. Ding Y, He L, Zhang Q, Huang Z, Che X, Hou J, Wang H, Shen H, Qiu L, Li Z, et al. Organ distribution of severe acute respiratory syndrome (SARS) associated coronavirus (SARS-CoV) in SARS patients: implications for pathogenesis and virus transmission pathways. J Pathol. 2004:203:622-30.

65. Widagdo W, Raj VS, Schipper D, Kolijn K, van Leenders G, Bosch BJ, Bensaid A, Segales J, Baumgartner W, Osterhaus A, et al. Differential expression of the Middle East respiratory syndrome coronavirus receptor in the upper respiratory tracts of humans and dromedary camels. J Virol. 2016;90:4838-42.

66. Wang W, Xu Y, Gao R, Lu R, Han K, Wu G, Tan W. Detection of SARS-CoV-2 in different types of clinical specimens. Jama. 2020;323:1843-4.

67. Wu P, Hao X, EHY L, Wong JY, KSM L, Wu JT, Cowling BJ, Leung GM. Realtime tentative assessment of the epidemiological characteristics of novel coronavirus infections in Wuhan, China, as at 22 January 2020. Euro Surveill. 2020;25:2000044.

68. Sanche S, Lin YT, Xu C, Romero-Severson E, Hengartner N, Ke R. High contagiousness and rapid spread of severe acute respiratory syndrome coronavirus 2. Emerg Infect Dis. 2020;26:1470-7.

69. Olsen SJ, Chang HL, Cheung TY, Tang AF, Fisk TL, Ooi SP, Kuo HW, Jiang $\mathrm{DD}$, Chen KT, Lando J, et al. Transmission of the severe acute respiratory syndrome on aircraft. N Engl J Med. 2003;349:2416-22.

70. Otter JA, Donskey C, Yezli S, Douthwaite S, Goldenberg SD, Weber DJ. Transmission of SARS and MERS coronaviruses and influenza virus in healthcare settings: the possible role of dry surface contamination. J Hosp Infect. 2016;92:235-50.

71. Yu IT, Qiu H, Tse LA, Wong TW. Severe acute respiratory syndrome beyond Amoy gardens: completing the incomplete legacy. Clin Infect Dis. 2014;58: 683-6.

72. Peiris JS, Chu CM, Cheng VC, Chan KS, Hung IF, Poon LL, Law Kl, Tang BS, Hon TY, Chan CS, et al. Clinical progression and viral load in a community outbreak of coronavirus-associated SARS pneumonia: a prospective study. Lancet. 2003;361:1767-72.

73. Li Q, Guan X, Wu P, Wang X, Zhou L, Tong Y, Ren R, Leung KSM, Lau EHY, Wong JY, et al. Early transmission dynamics in Wuhan, China, of novel coronavirus-infected pneumonia. N Engl J Med. 2020;382:1199-207.

74. Egloff C, Vauloup-Fellous C, Picone O, Mandelbrot L, Roques P. Evidence and possible mechanisms of rare maternal-fetal transmission of SARS-CoV-2. J Clin Virol. 2020;128:104447.

75. Pan Y, Zhang D, Yang P, Poon LLM, Wang Q. Viral load of SARS-CoV-2 in clinical samples. Lancet Infect Dis. 2020;20:411-2.
76. Xiao F, Tang M, Zheng X, Liu Y, Li X, Shan H. Evidence for Gastrointestinal Infection of SARS-CoV-2. Gastroenterology. 2020;158:1831-3.

77. Lu CW, Liu XF, Jia ZF. 2019-nCoV transmission through the ocular surface must not be ignored. Lancet. 2020;395:e39.

78. To KK, Tsang OT, Leung WS, Tam AR, Wu TC, Lung DC, Yip CC, Cai JP, Chan $J M$, Chik TS, et al. Temporal profiles of viral load in posterior oropharyngeal saliva samples and serum antibody responses during infection by SARSCoV-2: an observational cohort study. Lancet Infect Dis. 2020;20:565-74.

79. Zhang R, Li Y, Zhang AL, Wang Y, Molina MJ. Identifying airborne transmission as the dominant route for the spread of COVID-19. Proc Natl Acad Sci U S A. 2020;117:14857-63.

80. Gralinski LE, Baric RS. Molecular pathology of emerging coronavirus infections. J Pathol. 2015;235:185-95.

81. Channappanavar R, Perlman S. Pathogenic human coronavirus infections: causes and consequences of cytokine storm and immunopathology. Semin Immunopathol. 2017;39:529-39.

82. Behrens EM, Koretzky GA. Review: cytokine storm syndrome: looking toward the precision medicine era. Arthritis Rheumatol. 2017;69:1135-43.

83. Groneberg DA, Hilgenfeld R, Zabel P. Molecular mechanisms of severe acute respiratory syndrome (SARS). Respir Res. 2005;6:8.

84. Ye Q, Wang B, Mao J. The pathogenesis and treatment of the 'cytokine Storm' in COVID-19. J Inf Secur. 2020;80:607-13.

85. Lau SKP, Lau CCY, Chan KH, Li CPY, Chen H, Jin DY, Chan JFW, Woo PCY, Yuen KY. Delayed induction of proinflammatory cytokines and suppression of innate antiviral response by the novel Middle East respiratory syndrome coronavirus: implications for pathogenesis and treatment. J Gen Virol. 2013; 94:2679-90.

86. Qin C, Zhou L, Hu Z, Zhang S, Yang S, Tao Y, Xie C, Ma K, Shang K, Wang W, Tian DS. Dysregulation of immune response in patients with COVID-19 in Wuhan, China. Clin Infect Dis. 2020;71:762-8.

87. Huang C, Wang Y, Li X, Ren L, Zhao J, Hu Y, Zhang L, Fan G, Xu J, Gu X, et al. Clinical features of patients infected with 2019 novel coronavirus in Wuhan, China. Lancet. 2020;395:497-506.

88. Li CK, Wu H, Yan H, Ma S, Wang L, Zhang M, Tang X, Temperton NJ, Weiss RA, Brenchley JM, et al. T cell responses to whole SARS coronavirus in humans. J Immunol. 2008;181:5490-500.

89. Kimura H, Francisco D, Conway M, Martinez FD, Vercelli D, Polverino F, Billheimer D, Kraft M. Type 2 inflammation modulates ACE2 and TMPRSS2 in airway epithelial cells. J Allergy Clin Immunol. 2020;146:80-8.

90. Chen LD, Zhang ZY, Wei XJ, et al. Association between cytokine profiles and lung injury in COVID-19 pneumonia. Respir Res. 2020;21:201.

91. Jamilloux Y, Henry T, Belot A, Viel S, Fauter M, El Jammal T, Walzer T, François $B$, Sève $P$. Should we stimulate or suppress immune responses in COVID-19? Cytokine and anti-cytokine interventions. Autoimmun Rev. 2020; 19:102567.

92. Joob B, Wiwanitkit V. Novel Middle East respiratory syndrome and renal failure. Ren Fail. 2014;36:147.

93. Yin Y, Wunderink RG. MERS, SARS and other coronaviruses as causes of pneumonia. Respirology. 2018;23:130-7.

94. Borges do Nascimento IJ, Cacic N, Abdulazeem HM, von Groote TC, Jayarajah U, Weerasekara I, Esfahani MA, Civile VT, Marusic A, Jeroncic A, et al. Novel Coronavirus Infection (COVID-19) in Humans: A Scoping Review and Meta-Analysis. J Clin Med. 2020;9(4):941.

95. Gao Y, Li T, Han M, Li X, Wu D, Xu Y, Zhu Y, Liu Y, Wang X, Wang L. Diagnostic utility of clinical laboratory data determinations for patients with the severe COVID-19. J Med Virol. 2020;92:791-6.

96. Al-Tawfiq JA, Hinedi K, Abbasi S, Babiker M, Sunji A, Eltigani M. Hematologic, hepatic, and renal function changes in hospitalized patients with Middle East respiratory syndrome coronavirus. Int J Lab Hematol. 2017;39:272-8.

97. Wang JT, Sheng WH, Fang CT, Chen YC, Wang JL, Yu CJ, Chang SC, Yang PC. Clinical manifestations, laboratory findings, and treatment outcomes of SARS patients. Emerg Infect Dis. 2004;10:818-24.

98. Giannis D, Ziogas IA, Gianni P. Coagulation disorders in coronavirus infected patients: COVID-19, SARS-CoV-1, MERS-CoV and lessons from the past. J Clin Virol. 2020;127:104362

99. Hui DS, Chan PK. Clinical features, pathogenesis and immunobiology of severe acute respiratory syndrome. Curr Opin Pulm Med. 2008;14:241-7.

100. Azhar El, Hui DSC, Memish ZA, Drosten C, Zumla A. The Middle East Respiratory Syndrome (MERS). Infect Dis Clin North Am. 2019;33:891-905.

101. Wu Z, McGoogan JM. Characteristics of and important lessons from the coronavirus disease 2019 (COVID-19) outbreak in China: summary of a 
report of 72314 cases from the Chinese Center for Disease Control and Prevention. Jama. 2020;10.1001/jama.2020.2648.

102. Sun Y, Koh V, Marimuthu K, Ng OT, Young B, Vasoo S, Chan M, Lee VJM, De PP, Barkham T, et al. Epidemiological and clinical predictors of COVID-19. Clin Infect Dis. 2020;71:786-92.

103. Guan WJ, Ni ZY, Hu Y, Liang WH, Ou CQ, He JX, Liu L, Shan H, Lei CL, Hui DSC, et al. Clinical characteristics of coronavirus disease 2019 in China. N Engl J Med. 2020;382:1708-20.

104. Cummings MJ, Baldwin MR, Abrams D, Jacobson SD, Meyer BJ, Balough EM, Aaron JG, Claassen J, Rabbani LE, Hastie J, et al. Epidemiology, clinical course, and outcomes of critically ill adults with COVID-19 in New York City: a prospective cohort study. Lancet. 2020;395:1763-70.

105. Richardson S, Hirsch JS, Narasimhan M, Crawford JM, McGinn T, Davidson KW, Barnaby DP, Becker LB, Chelico JD, Cohen SL, et al. Presenting characteristics, comorbidities, and outcomes among 5700 patients hospitalized with COVID19 in the New York City area. Jama. 2020;323:2052-9.

106. Lingappan K, Karmouty-Quintana H, Davies J, Akkanti B, Harting MT. Understanding the age divide in COVID-19: why are children overwhelmingly spared? Am J Physiol Lung Cell Mol Physiol. 2020;319:L39-|44.

107. CDC COVID-19 Response Team. Coronavirus Disease 2019 In children United States, February 12-April 2, 2020. MMWR Morb Mortal Wkly Rep. 2020;69:422-6

108. Onder G, Rezza G, Brusaferro S. Case-fatality rate and characteristics of patients dying in relation to COVID-19 in Italy. Jama. 2020;10.1001/jama. 2020.4683.

109. Zheng Z, Peng F, Xu B, Zhao J, Liu H, Peng J, Li Q, Jiang C, Zhou Y, Liu S, et al. Risk factors of critical \& mortal COVID-19 cases: a systematic literature review and meta-analysis. J Inf Secur. 2020;81:e16-e25.

110. Yuki K, Fujiogi M, Koutsogiannaki S. COVID-19 pathophysiology: a review. Clin Immunol. 2020;215:108427

111. Lessler J, Reich NG, Brookmeyer R, Perl TM, Nelson KE, Cummings DA. Incubation periods of acute respiratory viral infections: a systematic review. Lancet Infect Dis. 2009;9:291-300.

112. Meltzer MI. Multiple contact dates and SARS incubation periods. Emerg Infect Dis. 2004;10:207-9.

113. Kim SH, Ko JH, Park GE, Cho SY, Ha YE, Kang JM, Kim YJ, Huh HJ, Ki CS, Jeong $\mathrm{BH}$, et al. Atypical presentations of MERS-CoV infection in immunocompromised hosts. J Infect Chemother. 2017;23:769-73.

114. Pung R, Chiew CJ, Young BE, Chin S, Chen MI, Clapham HE, Cook AR, Maurer-Stroh S, Toh M, Poh C, et al. Investigation of three clusters of COVID19 in Singapore: implications for surveillance and response measures. Lancet. 2020;395:1039-46.

115. Böhmer MM, Buchholz U, Corman VM, Hoch M, Katz K, Marosevic DV, Böhm S, Woudenberg T, Ackermann N, Konrad R, et al. Investigation of a COVID19 outbreak in Germany resulting from a single travel-associated primary case: a case series. Lancet Infect Dis. 2020;20:920-8.

116. Lauer SA, Grantz KH, Bi Q, Jones FK, Zheng Q, Meredith HR, Azman AS, Reich NG, Lessler J. The Incubation Period of Coronavirus Disease 2019 (COVID-19) from publicly reported confirmed cases: estimation and application. Ann Intern Med. 2020;172:577-82.

117. Linton NM, Kobayashi T, Yang Y, Hayashi K, Akhmetzhanov AR, Jung SM, Yuan B, Kinoshita R, Nishiura H. Incubation Period and Other Epidemiological Characteristics of 2019 Novel coronavirus infections with right truncation: a statistical analysis of publicly available case data. J Clin Med. 2020;9:538.

118. He W, Yi GY, Zhu Y. Estimation of the basic reproduction number, average incubation time, asymptomatic infection rate, and case fatality rate for COVID-19: meta-analysis and sensitivity analysis. J Med Virol. 2020;10.1002/ jmv.26041.

119. Backer JA, Klinkenberg D, Wallinga J. Incubation period of 2019 novel coronavirus (2019-nCoV) infections among travellers from Wuhan, China, 2028 January 2020. Euro Surveill. 2020;25:2000062.

120. Jiang $X$, Rayner S, Luo MH. Does SARS-CoV-2 has a longer incubation period than SARS and MERS? J Med Virol. 2020;92:476-8.

121. Ragab D, Salah Eldin H, Taeimah M, Khattab R, Salem R. The COVID-19 cytokine storm; What We Know So Far. Front Immunol. 2020;11:1446.

122. Zhang G, Zhang J, Wang B, Zhu X, Wang Q, Qiu S. Analysis of clinical characteristics and laboratory findings of 95 cases of 2019 novel coronavirus pneumonia in Wuhan, China: a retrospective analysis. Respir Res. 2020;21:74.

123. Baharoon S, Memish ZA. MERS-CoV as an emerging respiratory illness: A review of prevention methods. Travel Med Infect Dis. 2019;32:101520.
124. Guan WJ, Liang WH, Zhao Y, Liang HR, Chen ZS, Li YM, Liu XQ, Chen RC, Tang CL, Wang T, et al. Comorbidity and its impact on 1590 patients with COVID-19 in China: a nationwide analysis. Eur Respir J. 2020;55:2000547.

125. Tian Y, Rong L, Nian W, He Y. Review article: gastrointestinal features in COVID-19 and the possibility of faecal transmission. Aliment Pharmacol Ther. 2020;51:843-51.

126. laccarino G, Grassi G, Borghi C, Ferri C, Salvetti M, Volpe M. Age and Multimorbidity Predict Death Among COVID-19 Patients: Results of the SARS-RAS Study of the Italian Society of Hypertension. Hypertension. 2020; 76:366-72.

127. Wilder-Smith $A$, Teleman MD, Heng BH, Earnest A, Ling AE, Leo YS. Asymptomatic SARS coronavirus infection among healthcare workers, Singapore. Emerg Infect Dis. 2005;11:1142-5.

128. Leung GM, Lim WW, Ho LM, Lam TH, Ghani AC, Donnelly CA, Fraser C, Riley S, Ferguson NM, Anderson RM, Hedley AJ. Seroprevalence of IgG antibodies to SARS-coronavirus in asymptomatic or subclinical population groups. Epidemiol Infect. 2006;134:211-21.

129. Al-Tawfiq JA, Gautret P. Asymptomatic Middle East respiratory syndrome coronavirus (MERS-CoV) infection: extent and implications for infection control: a systematic review. Travel Med Infect Dis. 2019;27:27-32.

130. Yan Y, Chang L, Wang L. Laboratory testing of SARS-CoV, MERS-CoV, and SARS-CoV-2 (2019-nCoV): Current status, challenges, and countermeasures. Rev Med Virol. 2020;30:e2106.

131. Zhao J, Yuan Q, Wang H, Liu W, Liao X, Su Y, Wang X, Yuan J, Li T, Li J, et al. Antibody responses to SARS-CoV-2 in patients of novel coronavirus disease 2019. Clin Infect Dis. 2020;ciaa344.

132. Li K, Fang Y, Li W, Pan C, Qin P, Zhong Y, Liu X, Huang M, Liao Y, Li S. CT image visual quantitative evaluation and clinical classification of coronavirus disease (COVID-19). Eur Radiol. 2020;30:4407-16.

133. Shi H, Han X, Jiang N, Cao Y, Alwalid O, Gu J, Fan Y, Zheng C. Radiological findings from 81 patients with COVID-19 pneumonia in Wuhan, China: a descriptive study. Lancet Infect Dis. 2020;20:425-34.

134. Chan MS, Chan IY, Fung KH, Poon E, Yam LY, Lau KY. High-resolution CT findings in patients with severe acute respiratory syndrome: a pattern-based approach. AJR Am J Roentgenol. 2004;182:49-56.

135. Wong KT, Antonio GE, Hui DS, Lee N, Yuen EH, Wu A, Leung CB, Rainer TH, Cameron $\mathrm{P}$, Chung SS, et al. Thin-section CT of severe acute respiratory syndrome: evaluation of 73 patients exposed to or with the disease. Radiology. 2003;228:395-400

136. Ajlan AM, Ahyad RA, Jamjoom LG, Alharthy A, Madani TA. Middle East respiratory syndrome coronavirus (MERS-CoV) infection: chest CT findings. AJR Am J Roentgenol. 2014:203:782-7.

137. Das KM, Lee EY, Enani MA, AlJawder SE, Singh R, Bashir S, Al-Nakshbandi N, AIDossari K, Larsson SG. CT correlation with outcomes in 15 patients with acute Middle East respiratory syndrome coronavirus. AJR Am J Roentgenol. 2015;204:736-42.

138. Coello C, Fisk M, Mohan D, Wilson FJ, Brown AP, Polkey MI, Wilkinson I, Tal-Singer R, Murphy PS, Cheriyan J, Gunn RN. Quantitative analysis of dynamic (18) F-FDG PET/CT for measurement of lung inflammation. EJNMMI Res. 2017;7:47.

139. Qin C, Liu F, Yen TC, Lan X. (18) F-FDG PET/CT findings of COVID-19: a series of four highly suspected cases. Eur J Nucl Med Mol Imaging. 2020;47:1281-6.

140. Zhu Z, Lian X, Zeng Y, Wu W, Xu Z, Chen Y, Li J, Su X, Zeng L, Lv G. Pointof-care ultrasound-a new option for early quantitative assessment of pulmonary edema. Ultrasound Med Biol. 2020;46:1-10.

141. Radzina M, Biederer J. Ultrasonography of the Lung. Rofo. 2019;191:909-23.

142. Peng QY, Wang XT, Zhang LN. Findings of lung ultrasonography of novel corona virus pneumonia during the 2019-2020 epidemic. Intensive Care Med. 2020;46:849-50.

143. Tan G, Lian X, Zhu Z, Wang Z, Huang F, Zhang Y, Zhao Y, He S, Wang X, Shen $\mathrm{H}$, Lyu G. Use of Lung ultrasound to differentiate coronavirus disease 2019 (COVID-19) pneumonia from community-acquired pneumonia. Ultrasound Med Biol. 2020;50301-5629(20)30215-5.

144. Tian S, Xiong Y, Liu H, Niu L, Guo J, Liao M, Xiao SY. Pathological study of the 2019 novel coronavirus disease (COVID-19) through postmortem core biopsies. Mod Pathol. 2020;33:1007-14.

145. Tian S, Hu W, Niu L, Liu H, Xu H, Xiao SY. Pulmonary Pathology of EarlyPhase 2019 Novel coronavirus (COVID-19) pneumonia in two patients with Lung cancer. J Thorac Oncol. 2020;15:700-4.

146. Luo W, Yu H, Gou J, Li X, Sun Y, Li J, Liu L. Clinical pathology of critical patient with novel coronavirus pneumonia (COVID-19). Preprints. 2020; 2020020407. 
147. Xu Z, Shi L, Wang Y, Zhang J, Huang L, Zhang C, Liu S, Zhao P, Liu H, Zhu L, et al. Pathological findings of COVID-19 associated with acute respiratory distress syndrome. Lancet Respir Med. 2020;8:420-2.

148. Wang CF, Xie JX, Zhao L, Fei XC, Zhang H, Tan Y, Zhou L, Liu Z, Ren Y, Yuan $L$, et al. Aveolar macrophage activation and cytokine storm in the pathogenesis of severe COVID-19. Res Square. 2020;11:1229.

149. Wichmann D, Sperhake JP, Lütgehetmann M, Steurer S, Edler C, Heinemann A, Heinrich F, Mushumba H, Kniep I, Schröder AS, et al. Autopsy findings and venous thromboembolism in patients with COVID-19. Ann Intern Med. 2020;M20-2003.

150. Nicholls JM, Poon LL, Lee KC, Ng WF, Lai ST, Leung CY, Chu CM, Hui PK, Mak KL, Lim W, et al. Lung pathology of fatal severe acute respiratory syndrome. Lancet. 2003;361:1773-8.

151. Gu J, Gong E, Zhang B, Zheng J, Gao Z, Zhong Y, Zou W, Zhan J, Wang S, Xie $Z$, et al. Multiple organ infection and the pathogenesis of SARS.J Exp Med. 2005;202:415-24.

152. Polak SB, Van Gool IC, Cohen D, von der Thüsen JH, van Paassen J. A systematic review of pathological findings in COVID-19: a pathophysiological timeline and possible mechanisms of disease progression. Mod Pathol. 2020;1-11.

153. Bradley BT, Bryan A. Emerging respiratory infections: the infectious disease pathology of SARS, MERS, pandemic influenza, and legionella. Semin Diagn Pathol. 2019;36:152-9.

154. Cleri DJ, Ricketti AJ, Vernaleo JR. Severe acute respiratory syndrome (SARS). Infect Dis Clin N Am. 2010;24:175-202.

155. Ng DL, Al Hosani F, Keating MK, Gerber SI, Jones TL, Metcalfe MG, Tong S, Tao Y, Alami NN, Haynes LM, et al. Clinicopathologic, Immunohistochemical, and Ultrastructural findings of a fatal case of Middle East respiratory syndrome coronavirus infection in the United Arab Emirates, April 2014. Am J Pathol. 2016;186:652-8.

156. Alsaad KO, Hajeer AH, Al Balwi M, Al Moaiqel M, Al Oudah N, Al Ajlan A, AlJohani S, Alsolamy S, Gmati GE, Balkhy H, et al. Histopathology of Middle East respiratory syndrome coronovirus (MERS-CoV) infection - clinicopathological and ultrastructural study. Histopathology. 2018;72:516-24.

157. Chan RW, Hemida MG, Kayali G, Chu DK, Poon LL, Alnaeem A, Ali MA, Tao $\mathrm{KP}, \mathrm{Ng} \mathrm{HY}$, Chan MC, et al. Tropism and replication of Middle East respiratory syndrome coronavirus from dromedary camels in the human respiratory tract: an in-vitro and ex-vivo study. Lancet Respir Med. 2014;2: 813-22.

158. de Wit E, Rasmussen AL, Falzarano D, Bushmaker T, Feldmann F, Brining DL, Fischer ER, Martellaro C, Okumura A, Chang J, et al. Middle East respiratory syndrome coronavirus (MERS-CoV) causes transient lower respiratory tract infection in rhesus macaques. Proc Natl Acad Sci U S A. 2013;1 10:16598-603.

159. Singh VK, Mishra A, Singh S, Kumar P, Singh M, Jagannath C, Khan A. Emerging prevention and treatment strategies to control COVID-19. Pathogens. 2020;9:501.

\section{Publisher's Note}

Springer Nature remains neutral with regard to jurisdictional claims in published maps and institutional affiliations.

Ready to submit your research? Choose BMC and benefit from:

- fast, convenient online submission

- thorough peer review by experienced researchers in your field

- rapid publication on acceptance

- support for research data, including large and complex data types

- gold Open Access which fosters wider collaboration and increased citations

- maximum visibility for your research: over $100 \mathrm{M}$ website views per year

At $\mathrm{BMC}$, research is always in progress.

Learn more biomedcentral.com/submissions 